\title{
Antibodies to endothelial cells in Behçet's disease: cell-binding heterogeneity and association with clinical activity
}

\author{
Ricard Cervera, Margarita Navarro, Alfons López-Soto, Maria-Cinta Cid, \\ Josep Font, Jordi Esparza, Joan Carles Reverter, Joan Monteagudo, Miguel Ingelmo, \\ Alvaro Urbano-Márquez
}

Systemic Autoimmune Diseases Research Unit,

Department of

Internal Medicine,

Hospital Clinic,

Barcelona, Spain

R Cervera

$M$ Navarro

A López-Soto

$\mathrm{M}-\mathrm{C}$ Cid

J Font

J Esparza

$M$ Ingelmo

A Urbano-Márquez

Department of

Haemotherapy and

Haemostasis

J C Reverter

J Monteagudo

Correspondence to: Dr Ricard Cervera, Servei de Medicina Interna General, Hospital Clínic, Villarroel, 170,

08036-Barcelona, Catalonia Spain.

Accepted for publication 12 January 1994

\begin{abstract}
Objectives-To investigate the prevalence and characteristics of antibodies to endothelial cells (aEC) from large vessel and from microvasculature in a group of patients with Behçet's disease (BD) to determine the relationship of these antibodies with clinical and laboratory features of the disease.

Methods-Thirty patients with BD were prospectively and consecutively studied. The aEC were determined by enzymelinked immunosorbent assay (ELISA) using endothelial cells derived from human umbilical vein (large vessel) as well as from retroperitoneal adipose tissue (microvasculature).

Results-Fifteen patients (50\%) had aEC, either directed to large vessel $[8(26 \%)$ patients] or microvascular [13(43\%) patients] endothelial cells. The percentage of active patients was significantly higher in the aEC-positive group [12(80\%) patients] compared with the aEC-negative group [ $5(33 \%)$ patients] $(p<0.05)$.

Conclusions-Patients with BD have a high prevalence of aEC when microvascular endothelial cells are used in the assay. These antibodies seem to be a marker of disease activity in this condition, previously considered as negative for autoantibodies.
\end{abstract}

(Ann Rheum Dis 1994; 53: 265-267)

Antibodies to endothelial cells (aEC) are a heterogenous group of autoantibodies directed against antigens located in the cytoplasmic membrane of endothelial cells. They have been described in a variety of disorders that have in common an immune-mediated damage to the vessel wall. ${ }^{1-7}$ However, most assays for the detection of aEC use endothelial cells derived from human umbilical vein (large vessel) as antigenic source, while vascular damage involves small vessels in many of these conditions. As endothelial cells obtained from different tissues or from vessels of different sizes have some distinct biological and antigenic properties, ${ }^{8}$ a better system to detect $\mathrm{aEC}$ in these cases would be to use endothelial cells from microvasculature.
Behçet's disease (BD) is a multisystemic inflammatory disorder of unknown aetiology. The underlying pathology is vasculitis involving both small and large vessels. Previous studies, ${ }^{9-11}$ using human umbilical vein endothelial cells, have found a relatively low prevalence of aEC in this disease. However, no studies have been performed using microvascular endothelial cells.

In this study, we investigated the prevalence and characteristics of $\mathrm{aEC}$, using endothelial cells from human umbilical vein as well as from adipose tissue (microvasculature), in a group of patients with BD to determine the relationship of these antibodies with clinical and laboratory features of the disease.

\section{Patients and methods}

PATIENTS

Clinical and laboratory features of 30 patients with $\mathrm{BD}$ [16 female and 14 male, mean (SD) age 34 (9)], attending the Hospital Clínic of Barcelona as in- or outpatients, were prospectively and consecutively studied during the years 1989-92. All patients fulfilled the International Study Group for Behçet's Disease criteria for the diagnosis of BD. ${ }^{12}$ Major criteria were defined as oral ulcer, genital ulcer, eye lesions, and skin lesions. Minor criteria were defined as arthralgia, arthritis, central nervous system involvement, gastrointestinal involvement, and arterial and/ or venous thrombosis. Disease was considered to be clinically active when at least one major criterion and any number of minor criteria were present at the time of the study.

HUMAN UMBILICAL VEIN ENDOTHELIAL CELL CULTURE

Endothelial cells were isolated by collagenase (Sigma Chemical Co, St Louis, MO) digestion of human umbilical veins from several $A B H$ unrelated donors using the method described by Jaffeet $a l^{13}$ with minor modifications of our own. ${ }^{5}$

HUMAN ADIPOSE TISSUE MICROVASCULAR ENDOTHELIAL CELL CULTURE

Microvascular endothelial cells were obtained from retroperitoneal adipose tissue from a 
necropsy specimen. Tissue fragments were cut into $4 \mathrm{~mm}^{2}$ pieces, digested with $0 \cdot 1 \%$ collagenase at $27^{\circ} \mathrm{C}$ per 30 minutes, washed in PBS and pressed from the centre towards the periphery to release endothelial cells. The obtained mixed population was grown on gelatin-coated dishes in medium 199 (Gibco) with d-valine instead of 1 -valine to avoid fibroblast growth. The medium was supplemented with $20 \%$ iron-fortified calf serum (Hydine, Logan, VT), $200 \mathrm{microgr} / \mathrm{ml}$ endothelial cell growth supplement (Collaborative Research, Bedford, MA) and $50 \mathrm{U} / \mathrm{ml}$ sodium heparin (Fisher Scientific, Fair Town, NJ). Contaminating fibroblasts were eliminated by scraping and, by three weeks, an homogeneous population of actively growing endothelial cells ( $>95 \%$ von Willebrand factor antigen positive) was obtained. Cells were passed 1:4 every two weeks and used up to passage 8.

DETERMINATION OF aEC

The aEC were detected by ELISA as previously described. ${ }^{5}$ Results were expressed as binding index (BI) calculated from optical absorbance (OA) values as follows:

$\mathrm{BI}=\frac{\mathrm{OA}(\text { test sample) }-\mathrm{OA} \text { (blank) }}{\mathrm{OA}(\text { standard positive) }-\mathrm{OA}(\text { blank })} \times 100$

A positive sample was defined as a $\mathrm{BI}$ greater than $44 \%$ (mean +3 standard deviations of 50 healthy blood donors). The ELISA was reproducible with coefficients of variation within plates of $5 \%$ and between plates of $11 \%$.

\begin{tabular}{|c|c|c|c|c|c|c|c|c|}
\hline Number & Sex & Age & Activity & $H U V-a E C$ & $R A T-a E C$ & Uveitis & CNS & Thrombosis \\
\hline 1 & $\mathrm{~F}$ & 47 & Active & - & - & - & - & - \\
\hline 2 & $\mathrm{M}$ & 44 & Active & - & + & - & - & - \\
\hline 3 & $M$ & 45 & Active & + & + & + & - & + \\
\hline 4 & $M$ & 50 & Active & - & - & + & - & - \\
\hline 5 & $M$ & 53 & Active & + & + & + & - & + \\
\hline 6 & $\mathrm{~F}$ & 28 & Active & + & + & + & + & + \\
\hline 7 & $\mathrm{~F}$ & 25 & Active & + & + & + & - & - \\
\hline 8 & $\mathrm{~F}$ & 25 & Active & - & - & - & - & - \\
\hline 9 & F & 28 & Active & + & + & - & - & - \\
\hline 10 & $\mathrm{~F}$ & 30 & Active & - & - & + & - & - \\
\hline 11 & $\mathrm{~F}$ & 22 & Active & + & + & - & + & + \\
\hline 12 & $M$ & 35 & Active & - & - & + & - & - \\
\hline 13 & $M$ & 27 & Active & - & + & - & - & - \\
\hline 14 & $M$ & 38 & Active & - & + & + & - & - \\
\hline 15 & M & 19 & Active & - & + & + & + & - \\
\hline 16 & $\mathbf{M}$ & 46 & Active & - & - & + & - & - \\
\hline 17 & M & 35 & Active & - & + & + & - & - \\
\hline 18 & $\mathbf{F}$ & 24 & Inactive & - & + & - & - & - \\
\hline 19 & $M$ & 30 & Inactive & + & - & - & - & - \\
\hline 20 & F & 38 & Inactive & - & - & - & - & - \\
\hline 21 & F & 24 & Inactive & + & - & - & - & - \\
\hline 22 & F & 29 & Inactive & - & - & - & - & - \\
\hline 23 & F & 38 & Inactive & - & - & - & - & - \\
\hline 24 & F & 34 & Inactive & - & - & - & - & - \\
\hline 25 & F & 31 & Inactive & - & - & - & - & - \\
\hline 26 & $\mathrm{~F}$ & 48 & Inactive & - & - & - & - & - \\
\hline 27 & M & 29 & Inactive & - & - & - & - & - \\
\hline 28 & F & 28 & Inactive & - & - & - & - & - \\
\hline 29 & M & 32 & Inactive & - & - & - & - & - \\
\hline 30 & $M$ & 28 & Inactive & - & - & - & - & - \\
\hline
\end{tabular}

HUV-aEC $=$ antibodies to endothelial cells derived from human umbilical vein; RAT$\mathrm{aEC}=$ antibodies to endothelial cells derived from retroperitoneal adipose tissue; $\mathrm{CNS}=$ central nervous system involvement; Thrombosis = past thrombotic events.
STATISTICAL ANALYSIS

Conventional chi-square analysis and Fisher's exact test were used for analysing qualitative differences, Student's $t$ test for comparison of means in large samples of similar variance, and the non-parametric Mann-Whitney $U$ test in small samples.

\section{Results}

PREVALENCE OF aEC

Eight of 30 patients with $\mathrm{BD}(26 \%)$ were found to have a positive titre of aEC when human umbilical vein endothelial cells were used in the ELISA. Conversely, 13 patients $(43 \%)$ were positive for aEC when using endothelial cells derived from human adipose tissue.

Seven patients negative for aEC derived from human umbilical vein had aEC from human adipose tissue. Conversely, only two patients were positive for aEC from human umbilical vein and negative for aEC from microvasculature. In total, 15 patients $(50 \%)$ were considered to have aEC, either directed to large vessel or microvascular endothelial cells.

RELATIONSHIP BETWEEN AEC AND CLINICAL

\section{AND LABORATORY FEATURES}

Demographic, clinical and serological features of patients with $\mathrm{BD}$ are shown in the table. At the time of the study, 17 patients (57\%) had clinically active disease. Active eye lesions were present in 11 patients $(37 \%)$ and central nervous system involvement in three $(10 \%)$. No patient had gastrointestinal involvement or acute vascular thrombosis at this time. However, four patients (13\%) had a history of past thrombotic events (deep vein thrombosis in two cases and superior vena cava thrombosis in the remaining two cases). Conventional tests for detection of lupus anticoagulant, as well as for anticardiolipin, antineutrophil cytoplasmic, antinuclear, anti-DNA, anti-Ro(SSA), anti$\mathrm{La}(\mathrm{SSB})$, anti-RNP, and anti-Sm antibodies, were negative in all patients.

There was no significant difference between aEC-positive and -negative patients in age and sex distribution. However, the percentage of active patients was significantly higher in the aEC-positive group compared with the aECnegative group $(\mathrm{p}<0.05)$. Specifically, 12 $(80 \%)$ of 15 aEC-positive patients, but five $(33 \%)$ of the remaining 15 aEC- negative patients, had active disease. Furthermore, the prevalence of active eye lesions and central nervous system involvement at the time of the assay were higher in aEC-positive patients (53\% and $20 \%$, respectively) compared with the prevalence in aEC-negative patients $(20 \%$ and $0 \%$ ), although these differences did not reach statistical significance. All four patients with a history of past thrombotic events had both aEC derived from human umbilical vein and aEC from human adipose tissue. There were no differences in the other clinical and serological features between aEC-positive and -negative patients. 


\section{Discussion}

In this study, we have demonstrated that patients with $\mathrm{BD}$ have a high prevalence of aEC when microvascular endothelial cells are used in the assay. Pivetti-Pezzi et $a l^{9}$ have previously investigated the prevalence of aEC from human umbilical vein, as well as that of anticardiolipin antibodies, in a cohort of Italian patients with BD characterised by a high degree of genetic homogeneity and by the presence of retinal vasculitis. While an elevated prevalence of anticardiolipin antibodies was found, aEC were identified only in a minority of patients $(23 \%)$. In another study, Aydintug et $a l^{10}$ disclosed a statistically significant higher prevalence of aEC in a group of 72 Turkish patients with $\mathrm{BD}(18 \% \quad v \quad 0 \%$ in health controls). These aEC were not cytotoxic for the endothelial monolayers in vitro, but their presence correlated with an active disease and with acute thrombotic events. In contrast, anticardiolipin antibodies were negative in all Turkish patients. The discrepancy between these two reports can be related to the different disease activity or to the diverse genetic background of the patients included.

Our finding of a higher prevalence of aEC when endothelial cells derived from microvasculature were used in the ELISA is of special relevance. There is considerable structural and functional heterogeneity between endothelial cells from different vascular sites. ${ }^{8}$ Thus cultured endothelial cells from large vessels and from microvasculature may differ in surface antigens. As BD vasculitis affects both small and large vessels, it is conceivable that some aEC present in this disease can only be detected when microvascular endothelial cells are used in the ELISA. Conversely, it is interesting that we found aEC from human umbilical vein in all patients with a history of past thrombotic events involving large vessels (leg veins and superior vena cava).

The exact pathogenesis of vascular injury in $\mathrm{BD}$ is unclear but it is possible that immunological injury to endothelial cells may be important. High levels of von Willebrand factor antigen have been detected in some patients with this condition, ${ }^{9} 111415$ thus indicating damage to the endothelium. Whether aEC represent a primary event or they appear as a result of vascular damage remains controversial. No evidence for direct cytotoxicity induced by aEC has been detected in patients with BD. ${ }^{10}$ However, other changes in endothelial cell function rather than cell killing might be responsible for the pathogenesis of vascular damage. It is conceivable that these antibodies may disturb the normal physiological processes of endothelial cells and contribute to the development of vasculitis present in patients with $\mathrm{BD}$. On the other hand, Aydintug et $a l^{10}$ have proposed that the endothelial cell surface alterations caused by an as yet unknown agent in genetically predisposed individuals can lead to the formation of aEC in BD.

Whatever the relationship is between aEC and vascular damage in $\mathrm{BD}$, these antibodies - particularly those against microvascular endothelial cells - seem to be a marker of disease activity in this condition, previously considered as negative for autoantibodies. Similar correlations between aEC and disease activity have been reported in rheumatoid vasculitis, ${ }^{2}$ Wegener's granulomatosis, ${ }^{6}$ and lupus nephritis. ${ }^{1}$ However, serial determinations of aEC need to be performed in future longitudinal studies to confirm the clinical usefulness of these antibodies in monitoring disease activity.

This work was supported in part by grants FISS 92/0385 and FISS 93/0603 from Fondo de Investigaciones Sanitarias de la Seguridad Social of Spain. Margarita Navarro is a research fellow sponsored by a grant from the Hospital Clinic of Barcelona.

1 D'Cruz D P, Houssiau F A, Ramírez G, et al. Antibodies to endothelial cells in systemic lupus erythematosus: a potential marker for nephritis and vasculitis. Clin Exp Immunol 1991; 85: 254-61.

2 Heurkens A H M, Hiemstra P S, Lafeber G J M, Daha M R, Breedveld F C. Anti-endothelial cell antibodies in patients with rheumatoid arthritis complicated by patients with rheumatoid arthritis comp
vasculitis. Clin Exp Immunol 1989; 78: 7-12.

3 Rosenbaum J, Pottinger B E, Woo P, et al. Measurement and characterisation of circulating anti-endothelial cell IgG in connective tissue diseases. Clin Exp Immunol 1988; 72 450-6.

4 Cervera R, Ramírez G, Fernández-Solà J, et al. Antibodies to endothelial cells in dermatomyositis: Association with interstitial lung disease. $B M F$ 1991; 302: 880-1.

5 Cervera $R$, Khamashta $M$ A, Font J, et al. Antiendothelial cell antibodies in patients with the antiphospholipid syndrome. Autoimmunity 1991; 11: 1-6.

6 Ferraro G, Meroni P L, Tincani A, et al. Anti-endothelial cell antibodies in patients with Wegener's granulomatosis and micropolyarteritis. Clin Exp Immunol 1990; 79: and micris.

7 Frampton G, Jayne D R W, Perry G J, Lockwood C M, Cameron J S. Autoantibodies to endothelial cells and neutrophil cytoplasmic antigens in systemic vasculitis. Clin Exp Immunol 1990; 82: 227-32.

8 Lelkes P I. Conference report: Endothelial cell heterogeneity and organ specificity. Endothelium 1993; 1: 69-70.

9 Pivetti-Pezzi P, Priori R, Catarinelli G, et al. Markers of vascular injury in Behçet's disease associated with retinal vasculitis. Ann Ophtalmon (US) 1992; 24: 411-14.

10 Aydintug A O, Tokgöz G, D'Cruz D P, et al. Antibodies to endothelial cells in patients with Behçet's disease. Clin Immunol Immunopathol 1993; 67: 157-62.

11 Direskeneli H, Keser D, D'Cruz D, et al. Anti-endothelial cell antibodies and endothelial cell dysfunction in Behçet's disease (abstract). Rev Med Intern (Paris) 1993; 14 (suppl 1): 134s.

12 International Study Group for Behçet's Disease. Criteria for diagnosis of Behçet's disease. Lancet 1990; 335: 1078-80.

13 Jaffe E A, Nachman R L, Recker C G, Minick C R. The culture of human endothelial cells derived from umbilical veins. Identification by morphologic and immunologic veins. Identification by morphologic and
criteria. $\mathcal{F}$ Clin Invest 1973; 52: 2754-56.

14 Aydintug A O, Tokgöz G, Jedryka-Góral A, et al. von Willebrand factor antigen in patients with Behçet's disease (abstract). Rev Med Intern (Paris) 1993; 14 (suppl 1): $132 \mathrm{~s}$.

15 Madanat W, Nassonov E, Rehsetnyak $\mathrm{T}$, et. al. Antiendothelial cell antibodies (AECA), von Willebrand (LA) and anticardiolipin antibodies (aCL) in Behçet's diA) and anticardiolipin antibodies (aCL) in Behçet's 1): $132 \mathrm{~s}$. 